\title{
Upregulation of antioxidant and autophagy pathways via NRF2 activation protects spinal cord neurons from ozone damage
}

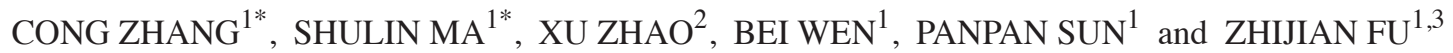 \\ ${ }^{1}$ Department of Pain Management, Shandong Provincial Hospital, Cheeloo College of Medicine, \\ Shandong University; Departments of ${ }^{2}$ Anesthesiology and ${ }^{3}$ Pain Management, Shandong Provincial Hospital \\ Affiliated to Shandong First Medical University, Jinan, Shandong 250021, P.R. China
}

Received September 23, 2020; Accepted March 9, 2021

DOI: $10.3892 / \mathrm{mmr} .2021 .12067$

\begin{abstract}
Ozone therapy can relieve multiple types of pain but exhibits potential neurotoxicity, the mechanism of which is unclear. The present study aimed to identify the role of nuclear factor (erythroid-derived-2)-related 2 (NRF2) in preventing spinal cord injury caused by ozone overdose. Primary neuronal cells were extracted from newborn Wistar rats and authenticated by immunofluorescence using anti-microtubule-associated protein 2 as a cell type-specific marker. Cell viability assay with different ozone concentrations $(0,10,20,30$ and $40 \mu \mathrm{g} / \mathrm{ml})$ was used to determine the concentration that caused primary neuron injury; $30 \mathrm{~min}$ of $40 \mu \mathrm{g} / \mathrm{ml}$ ozone therapy notably decreased cell viability to $71 \%$. In order to test the effects of ozone, the cells were divided into five treatment groups [0-, 30- and $40 \mu \mathrm{g} / \mathrm{ml}$ ozone, tert-butylhydroquinone (tBHQ) $+40 \mu \mathrm{g} / \mathrm{ml}$ ozone (T40) and tBHQ (T0)]. Cells in the T40 and T0 groups received $40 \mu \mathrm{mol} / \mathrm{lBHQ}$ on the fifth day of SCN cultivation. Reverse transcription-quantitative PCR and western blotting showed that protein expression levels of heme oxygenase-1 (HO-1) and mRNA expression levels of HO-1 and NRF2 were decreased. NRF2, ubiquitin-binding protein p62 and microtubule-associated proteins 1A/1B light chain 3B expression levels were decreased following treatment with $40 \mu \mathrm{g} / \mathrm{ml}$ ozone. Immunofluorescence showed that
\end{abstract}

Correspondence to: Professor Zhijian Fu, Department of Pain Management, Shandong Provincial Hospital, Cheeloo College of Medicine, Shandong University, 324 Jingwu Road, Jinan, Shandong 250021, P.R. China

E-mail: zhijian_fu@163.com

${ }^{*}$ Contributed equally

Abbreviations: ARE, antioxidant response element; NRF2, nuclear factor (erythroid-derived-2)-related 2 factor; KEAP1, Kelch-like ECH-associated protein 1; tBHQ, Tert-butylhydroquinone; HG, High Glucose; Gln, L-glutamine; PLL, Poly-L-lysine hydrobromide; SCN, Spinal cord neuron; HO-1, heme oxygenase1; CCK8, Cell Counting Kit-8; PI, phosphatase inhibitor

Key words: autophagy, NRF2, ozone, spinal cord neurons, tBHQ
NRF2 nuclear expression levels also decreased following $40 \mu \mathrm{g} / \mathrm{ml}$ ozone treatment. However, cells in the T40 group did not display decreased NRF2 nuclear expression levels. Normal/Apoptotic/Necrotic Cell Detection kit revealed that necrosis rate increased following treatment with $40 \mu \mathrm{g} / \mathrm{ml}$ ozone; however, the T40 group did not exhibit this increased necrosis. At $40 \mu \mathrm{g} / \mathrm{ml}$, ozone increased spinal cord neuron (SCN) death in vitro. Moreover, treatment with $40 \mu \mathrm{g} / \mathrm{ml}$ ozone damaged SCNs. The p62/NRF2/antioxidant response element pathway prevented such injury. tBHQ activated this pathway, upregulated autophagy and increased local nuclear NRF2 concentration, thus enhancing the antioxidant system to protect SCNs from injury caused by high concentrations of ozone.

\section{Introduction}

Ozone therapy is widely used in clinics to treat herniated lumbar discs and osteoarthritis $(1,2)$ due to its effectiveness and convenient application. However, certain studies have shown that ozone overdose may induce an oxidant-antioxidant imbalance, resulting in damage to the nervous system $(3,4)$. The nervous system is sensitive to this imbalance due to its high demand for oxygen. The spinal cord may be preferentially damaged in cases where ozone overdose occurs during ozone therapy for lumbar disc herniation (5). However, the mechanism by which ozone overdose damages spinal cord neurons (SCNs) is poorly understood (6). Nonetheless, it has been shown that ozone-induced neurotoxicity is associated with its strong oxidizing properties (7).

Liu et al (4) reported that ozone activates endoplasmic reticulum stress-mediated $\mathrm{Ca}^{2+}$ release and the calmodulin-dependent protein kinase II/MAPK signaling pathway to produce neurotoxicity in SCNs. Both autophagy and the nuclear factor (erythroid-derived-2)-related 2 factor/antioxidant response element (NRF2/ARE) signaling pathway are key contributors to the antioxidant system. Kelch-like ECH-associated protein 1 (KEAP1) associates with and negatively regulates NRF2 $(8,9)$. This interaction may be disrupted by ubiquitin-binding protein $\mathrm{p} 62$, which promotes degradation of KEAP1 and maintains levels of NRF2. Through a positive feedback mechanism, NRF2 activates p62 to maintain redox homeostasis (10). Moreover, autophagy and the 
NRF2/ARE antioxidant pathway influence formation, injury, repair, degeneration and aging of the nervous system (11-17). Tert-butylhydroquinone (tBHQ), an activator of NRF2, has been used to investigate the function of NRF2 in inflammation, antioxidative stress response, autophagy and neuroprotection (18-21). However, there is a lack of evidence regarding the function of tBHQ in SCN injury by ozone overdose. In the present study, the Cell Counting Kit 8 (CCK8) was used to detect cell viability to identify an appropriate concentration of medical ozone for subsequent experiments. Reverse transcription-quantitative PCR (RT-qPCR) and western blotting were performed to detect alterations in the mRNA and protein expression levels of NRF2, heme oxygenase 1 (HO-1), P62 and LC3. Immunofluorescence assays were conducted to detect the expression of nuclear NRF2. The Normal/Apoptotic/Necrotic Cell Detection Kit (AO/EB) was used to detect the rate of live, apoptotic and necrotic cells. In the present study, tBHQ was used to activate NRF2 to investigate the role of the p62/NRF2/ARE pathway in SCN injury caused by ozone overdose.

\section{Materials and methods}

Reagents, chemicals and antibodies. Neonatal Wistar rats were purchased from the Experimental Animal Center of Shandong University. All programs involving the use of animals were performed in accordance with the Guide for the Care and Use of Laboratory Animals of the National Institutes of Health (NIH; olaw.nih.gov/sites/default/files/Guidefor-the-Care-and-Use-of-Laboratory-Animals.pdf) and were approved by the Animal Care and Use Committee of the School of Medicine of Shandong University (Shandong, China). Poly-L-lysine hydrobromide (PLL; Beijing Solarbio Science \& Technology Co., Ltd.), FBS (Biological Industries), DMEM-High Glucose (HG; Invitrogen; Thermo Fisher Scientific, Inc.), B27 (Invitrogen; Thermo Fisher Scientific, Inc.), L-glutamine (Gln; Beijing Solarbio Science \& Technology Co., Ltd.), Neurobasal-A medium (Thermo Fisher Scientific, Inc.), penicillin-streptomycin (Beijing Solarbio Science \& Technology Co., Ltd.), PBS (Gibco; Thermo Fisher Scientific, Inc.), Tyrisin (Gibco; Thermo Fisher Scientific, Inc.), 4\% paraformaldehyde (Beijing Solarbio Science \& Technology Co., Ltd.), and normal goat serum (Abbkine Scientific Co., Ltd.) were used to extract and cultivate primary neuronal cells. The antibodies included anti-MAP2 antibody (rabbit anti-rat IgG; cat. no. 17490-1-AP; ProteinTech Group, Inc.), Dylight 594 goat anti-rabbit IgG (H+L; cat. no. A23420; Abbkine Scientific Co., Ltd.), Dylight 488 goat anti-rabbit IgG (H+L; cat. no. A23220; Abbkine Scientific Co., Ltd.), anti-NRF2 NFE2L2 (rabbit anti-rat; cat. no. 16396-1-AP; ProteinTech Group, Inc.), anti-GAPDH (EPR16891 rabbit anti-rat; cat. no. ab181602; Abcam), anti-light chain (LC)3B (EPR18709 rabbit anti-rat; cat. no. ab192890; Abcam), anti-sequestosome (SQSTM)1/p62 (EPR4844 rabbit anti-rat; cat. no. ab109012; Abcam), anti-HO-1 (EPR1390Y rabbit anti-rat; cat. no. ab68477; Abcam) and horseradish peroxidase (HRP)-goat anti-rabbit IgG (H+L; cat. no. SA00001-2; ProteinTech Group, Inc.). Other reagents and kits included Fluorescent Mounting Media (cat. no. S2100-5; Beijing Solarbio Science \& Technology Co., Ltd.), CCK8 (Abcam), PMSF (cat. no. P1260-1; Beijing
Solarbio Science \& Technology Co., Ltd.), AG RNAex Pro Reagent (Accurate Biotechnology; cat. no. AG21101), Custom DNA/RNA oligos (BioSune; cat. no. 5002), Pro Taq HS SYBR Green quantitative (q)PCR kit (AG, cat. no. AG11701), Evo M-MLV RT Premix for qPCR (AG, cat. no. AG11706), tBHQ (MedChemExpress; cat. no. HY-100489), bicinchoninic acid (BCA) protein assay kit (cat. no. PC0020-500; Beijing Solarbio Science \& Technology Co., Ltd.), enhanced chemiluminescence (ECL) substrate (cat. no. WBKLS0100; Merck $\mathrm{KGaA}$ ) and the Normal/Apoptotic/Necrotic Cell Detection kit (cat. no. KGA501; Nanjing KeyGen Biotech Co., Ltd.).

Primary culture of newborn Wistar rat neurons. A total of 400 Wistar rats (weight, 4-6 g; age, <24 h) were euthanized by decapitation and dehydrated by soaking in $75 \%$ alcohol for 3 min at $0^{\circ} \mathrm{C}$. The spinal cord was removed and sectioned into $0.5-1 \mathrm{~mm}^{3}$ pieces. The sections were incubated in $3 \mathrm{ml} 0.125 \%$ trypsin for $15 \mathrm{~min}$ at $37^{\circ} \mathrm{C}$. The digestion was terminated by incubating the sections in isopycnic FBS for $3 \mathrm{~min}$ at room temperature, after which the liquid supernatant was removed. A temporary medium, composed of FBS, DMEM-HG and penicillin-streptomycin, was added, followed by mixing and agitating the solution 15 times with a pipette. The liquid supernatant was aspirated into a new centrifuge tube following 2 min incubation at room temperature; this step was repeated twice. The supernatant was filtered and the cells were counted using a BX51 light microscope (magnification, x400; Olympus Corporation).

The cells were plated onto a culture plate $\left(1 \times 10^{7} / \mathrm{cm}^{2}\right)$ that had been coated 3 times with PLL. The cells were incubated for $4 \mathrm{~h}$ at $37^{\circ} \mathrm{C}$, after which the temporary medium was removed. PBS was used to wash the plate 2-3 times and medium was replaced with complete medium (97.5 Neurobasal-A medium, 1.0 B27, $0.5 \mathrm{Gln}$ and $1.0 \%$ penicillin-streptomycin) for incubation at $37^{\circ} \mathrm{C}$. During the culture, half of the culture medium was changed every 3 days; on the seventh day, cells were harvested for subsequent experiments.

Immunofluorescence assay. In order to authenticate the purity of cell culture, cells were cultured for 7 days. The cells were washed 3 times (5 min each) with PBS and immobilized by incubation in $4 \%$ paraformaldehyde for $30 \mathrm{~min}$ at room temperature. After immobilization, the cells were washed 3 times (5 min each) with PBS again and blocked with $10 \%$ goat serum for $1 \mathrm{~h}$ in an incubator at $37^{\circ} \mathrm{C}$. Subsequently, cells were washed 3 times (5 min each) to remove the goat serum. Anti-MAP2 monoclonal antibody (1:300) attenuated by goat serum was added, followed by overnight incubation in a refrigerator at $4^{\circ} \mathrm{C}$. The following day, cells were washed 3 times (5 min each) with PBS, then Dylight 594 Goat anti-rabbit IgG $(\mathrm{H}+\mathrm{L} ; 1: 200)$ attenuated by $100 \%$ goat serum was added, followed by incubation at room temperature for $1 \mathrm{~h}$. The secondary antibody was removed by washing the cells 3 times (5 min each) with PBS.DAPI $(10 \mu \mathrm{g} / \mathrm{ml})$ was added to the cells and incubated for $10 \mathrm{~min}$ at room temperature, followed by washing with PBS to remove excess DAPI. A fluorescent mounting media (cat. no. S2100-5; Beijing Solarbio Science \& Technology Co., Ltd.) was added, and the cells were observed under a confocal immunofluorescence microscope (magnification, $\mathrm{x} 400$ ). The same procedure was performed with 
A Day 3

Day 5

Day 7

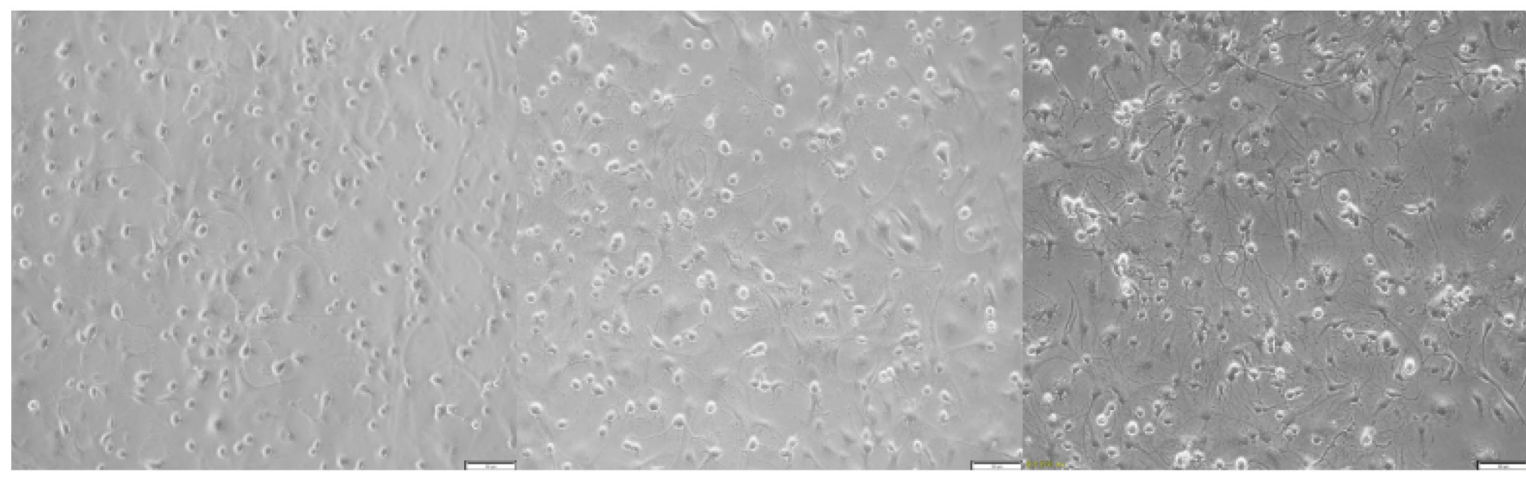

B

DAPI

MAP2

Merge

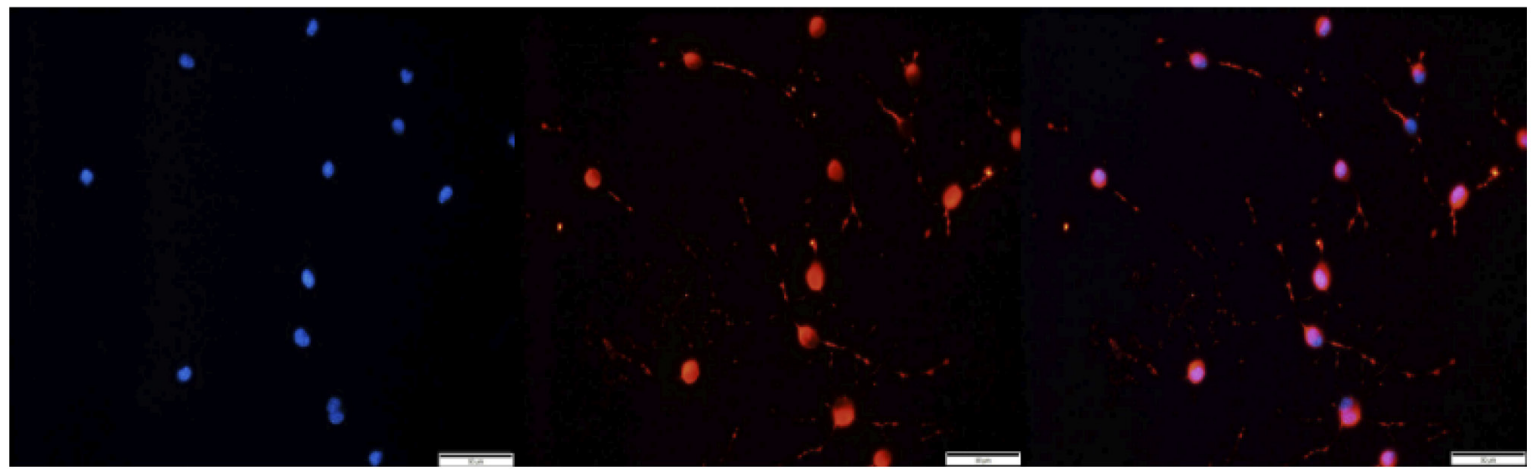

Figure 1. Extraction, cultivation and authentication of SCNs. (A) Cultivated SCNs on days 3, 5 and 7 (scale bar, $100 \mu \mathrm{m}$ ). (B) Immunofluorescent staining of SCNs using neuronal cytoskeletal marker MAP2 (red) and DAPI (blue) (scale bar, $50 \mu \mathrm{m}$ ). SCN, spinal cord neuron.

anti-NRF2 NFE2L2 (1:300) and Dylight 488 Goat anti-rabbit IgG $(\mathrm{H}+\mathrm{L})(1: 200)$ to compare expression levels of NRF2 in the nucleus.

CCK8 assay. In order to determine the appropriate concentration of medical ozone for future assays, the cells were cultured in a 96-well plate (100 $\mu \mathrm{l} /$ well) for 7 days. Different concentrations of medical ozone $(0,10,20,30$ and $40 \mu \mathrm{g} / \mathrm{ml})$ were administered to the cells for $30 \mathrm{~min}$ at room temperature. Following the manufacturer's protocol, $10 \mu \mathrm{l}$ CCK8 solution was added to each well. The plate was incubated at $37^{\circ} \mathrm{C}$ for $4 \mathrm{~h}$ and the absorbance was measured at $450 \mathrm{~nm}$.

RT-qPCR analysis. Total RNA was extracted from SCNs using AG RNAex Pro Reagent according to the manufacturer's protocol. The sample concentration was subsequently measured and Evo M-MLV RT Premix for qPCR (AG) was used to synthesize cDNA (500 ng total RNA per $10 \mu \mathrm{l}$ reaction mixture) according to the manufacturer's instructions. The Pro Taq HS SYBR Green qPCR kit was used for RT-qPCR to quantify RNA on a Roche LightCycler480 system. The following thermocycling conditions were used for qPCR: $95^{\circ} \mathrm{C}$ for $30 \mathrm{sec}$; followed by 40 cycles of $95^{\circ} \mathrm{C}$ for $5 \mathrm{sec}$ and $60^{\circ} \mathrm{C}$ for $30 \mathrm{sec} . \beta$-actin was used as an internal control. The $2^{-\Delta \Delta \mathrm{Cq}}$ method (22) was used to calculate the fold changes in gene expression levels. The primer sequences were as follows: $\beta$-actin forward, 5'-CTCTGTGTGGATTGGTGGCT-3' and reverse, 5'-CGCAGCTCAGTAACAGTCCG-3'; NRF2 forward, 5'-CCATTTACGGAGACCCACCG-3' and reverse,
5'-TTTGACACTTCCAGGGGCAC-3'; p62 forward, 5'-CTG AGAAGGACTCGCTCGAC-3' and reverse, 5'-TCAGTACCC GCTCTTTCAGC-3'; HO-1 forward, 5'-GAGCGAAACAAG CAGAACCC-3' and reverse, 5'-ACCTCGTGGAGACGCTTT AC-3' and LC3, forward, 5'-TTGGTCAAGATCATCCGG CG-3' and reverse, 5'-GTCAGCGATGGGTGTGGATA-3'.

Western blotting. SCNs were lysed using RIPA lysis buffer with PMSF and phosphatase inhibitor (PI; RIPA:PMSF:PI=100:1:1), stored on ice for $30 \mathrm{~min}$ and vortexed every $5 \mathrm{~min}$. The supernatant was collected following centrifugation at $16,000 \mathrm{x} \mathrm{g}$ for $30 \mathrm{~min}$ at $4^{\circ} \mathrm{C}$. The BCA protein assay kit was used to measure the total protein concentration. Sodium dodecyl sulfate-polyacrylamide gel electrophoresis (12\%) was used to separate the proteins $(30 \mu \mathrm{g} / \mathrm{lane})$. After loading the samples, the gel was pre-run at $75 \mathrm{~V}$ for $45 \mathrm{~min}$ and then at $110 \mathrm{~V}$ for $\sim 90 \mathrm{~min}$. The protein was transferred to a polyvinylidene fluoride membrane via electrotransformation at $220 \mathrm{~mA}$ (1 min per molecular weight). The membranes were blocked in $5 \%$ skimmed milk for $60 \mathrm{~min}$ at room temperature, followed by 3 washes for $5 \mathrm{~min}$ each in TBST (1\% Tween-20). The membranes were then incubated overnight with primary anti-NRF2 NFE2L2 $(1: 2,000)$, anti-GAPDH (1:5,000), anti-LC3B (1:5,000), anti-SQSTM1/p62 $(1: 10,000)$ and anti-HO-1 antibody $(1: 2,000)$ at $4^{\circ} \mathrm{C}$. The primary antibody was removed by washing the membranes three times with TBST (10 min each). The membranes were then incubated for $1 \mathrm{~h}$ at room temperature with HRP-Goat anti-rabbit IgG $(\mathrm{H}+\mathrm{L} ; 1: 5,000)$ antibody, followed by three 10 -min washes. The membranes were developed using ECL substrates for 


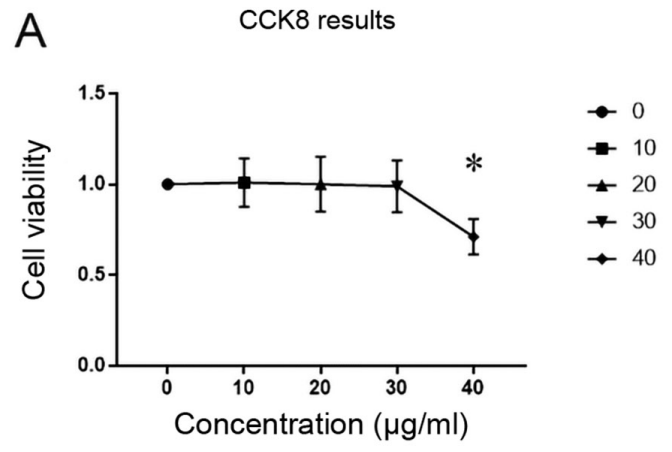

B

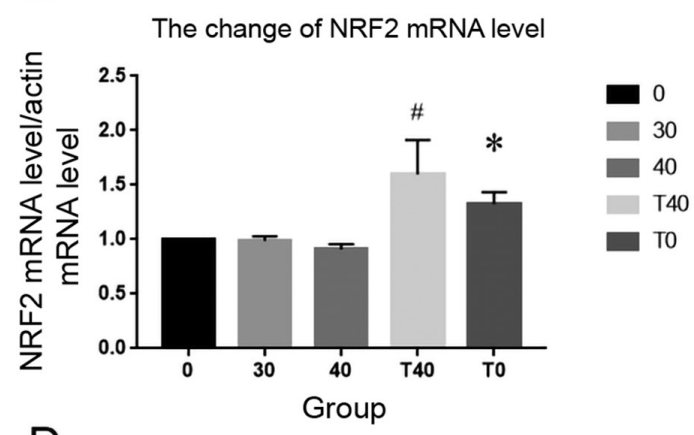

D The change of HO1 mRNA level

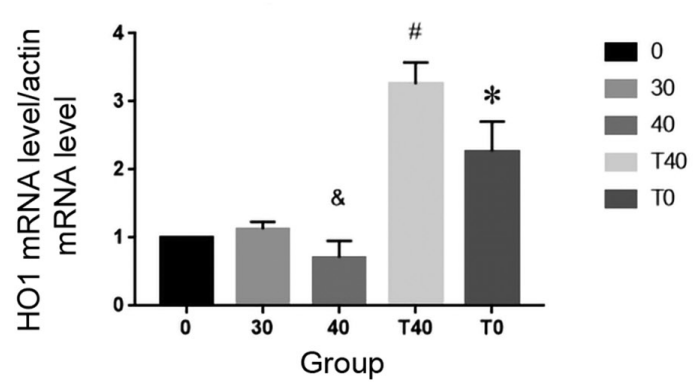

C

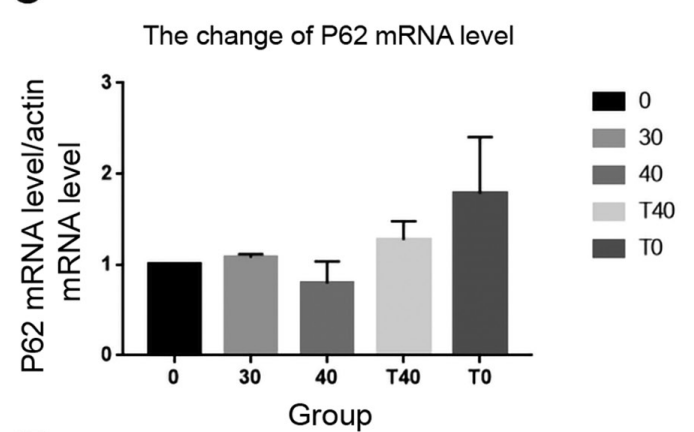

E

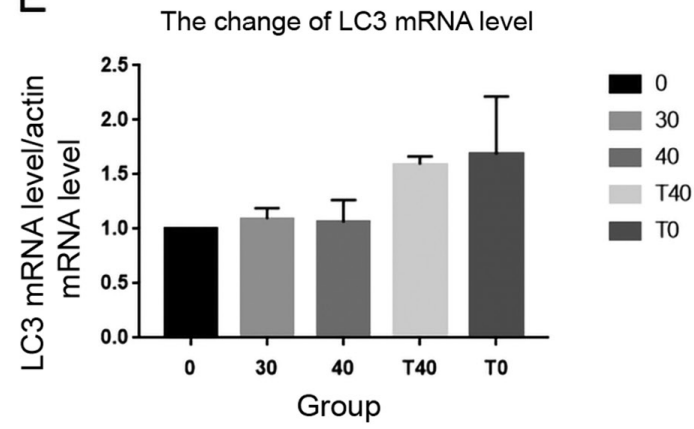

Figure 2. CCK8 and reverse transcription-quantitative PCR. (A) CCK8 assay showed that $40 \mu \mathrm{g} / \mathrm{ml}$ ozone decreased cell viability by $71 \%$. Changes in mRNA levels of (B) NRF2, (C) p62, (D) HO-1 and (E) LC3 in each group. $\beta$-actin was used as the internal control. The data are presented as the mean \pm SD (n=3). ${ }^{*} \mathrm{P}<0.05$ vs. $0 \mu \mathrm{g} / \mathrm{ml}$ ozone; ${ }^{\&} \mathrm{P}<0.05$ vs. $30 \mu \mathrm{g} / \mathrm{ml}$ ozone; ${ }^{\sharp} \mathrm{P}<0.05$ vs. $40 \mu \mathrm{g} / \mathrm{ml}$ ozone. T40, $40 \mu \mathrm{mol} / 1 \mathrm{tBHQ}+40 \mu \mathrm{g} / \mathrm{ml}$ ozone; T0, $40 \mu \mathrm{mol} / 1 \mathrm{tBHQ} ; \mathrm{CCK} 8, \mathrm{Cell}$ Counting Kit-8; NRF2, nuclear factor (erythroid-derived-2)-related 2 factor; HO-1, heme oxygenase 1; tBHQ, tert-butylhydroquinone.

detection. The band densities were quantified by ImageJ software (version 1.51 ; NIH).

Acridine orangelethidium bromide $(A O / E B)$ assay. The Normal/Apoptotic/Necrotic Cell Detection kit was used to calculate the necrosis and apoptosis rates. SCNs were extracted and cultured for 7 days. SCNs were subsequently subjected to digestion ( $0.125 \%$ trypsin for $10 \mathrm{~min})$, centrifugation (72 $\mathrm{x} \mathrm{g}$ for $4 \mathrm{~min}$ at room temperature) and resuspension in PBS $\left(1 \times 10^{6}\right.$ cells $\left./ \mathrm{ml}\right)$. Mixed dye reagent $(1 \mu \mathrm{l}$ dye reagent 1 :dye reagent $2=1: 1)$ was added to $25 \mu \mathrm{l}$ cells and mixed thoroughly. A total of $10 \mu \mathrm{l}$ mixture was dropped on glass slides and covered with a cover slip. A total of 200 cells were observed under a confocal immunofluorescence microscope at x100 magnification and necrosis and apoptosis rates were calculated.

Statistical analysis. SPSS (version 23.0; IBM Corp.) was used for statistical analysis. The data are expressed as the mean $\pm \mathrm{SD}(\mathrm{n} \geq 3)$. Data were analyzed by one-way ANOVA, followed by Tukey's post hoc test for multiple comparisons. $\mathrm{P}<0.05$ was considered to indicate a statistically significant difference.

\section{Results}

Primary neuron authentication. MAP2 was used as a specific neuronal marker to verify the purity of the primary neuron extraction (Fig. 1A and B). The results showed purity $>90 \%$ (calculated according to the formula: MAP2 staining/DAPI staining), which was considered acceptable for use in subsequent experiments.

Medical ozone at $40 \mu \mathrm{g} / \mathrm{ml}$ impacts cell viability. CCK8 assay was performed to determine assess cell viability and determine an appropriate experimental concentration of ozone for subsequent experiments. No notable change in absorbance at $520 \mathrm{~nm}$ was observed in cells treated with $10-30 \mu \mathrm{g} / \mathrm{ml}$ 


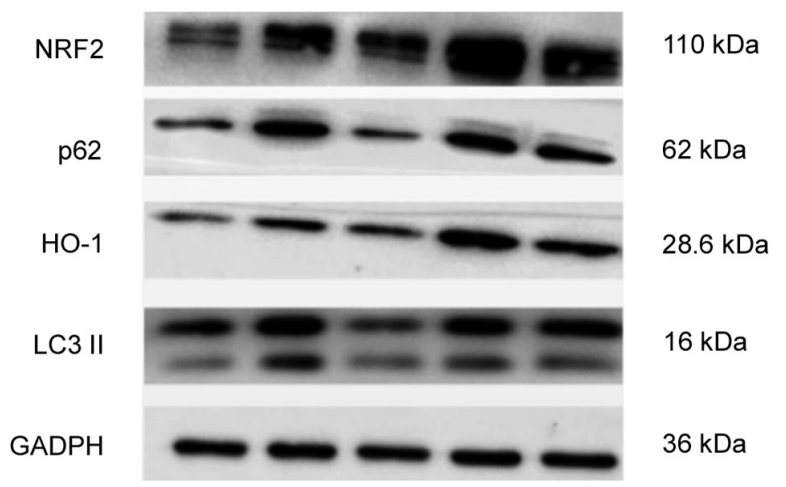

A

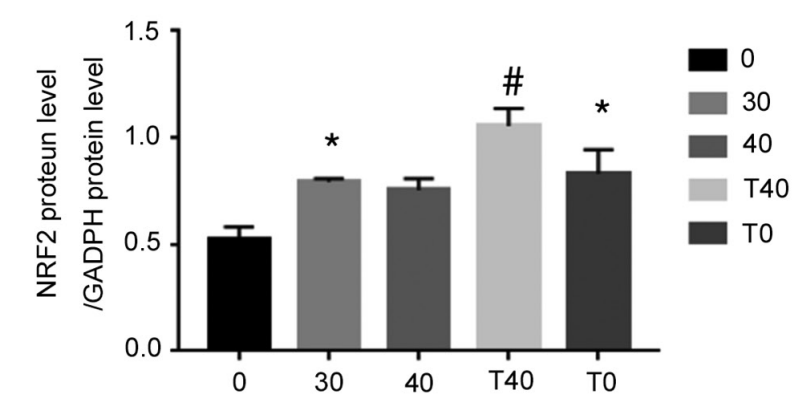

C

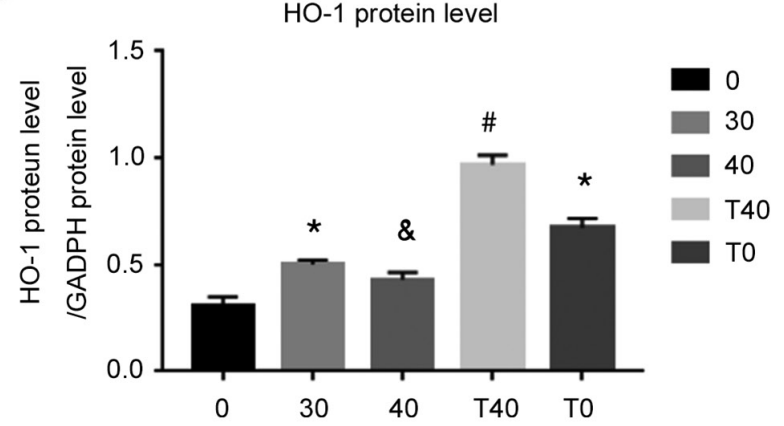

B

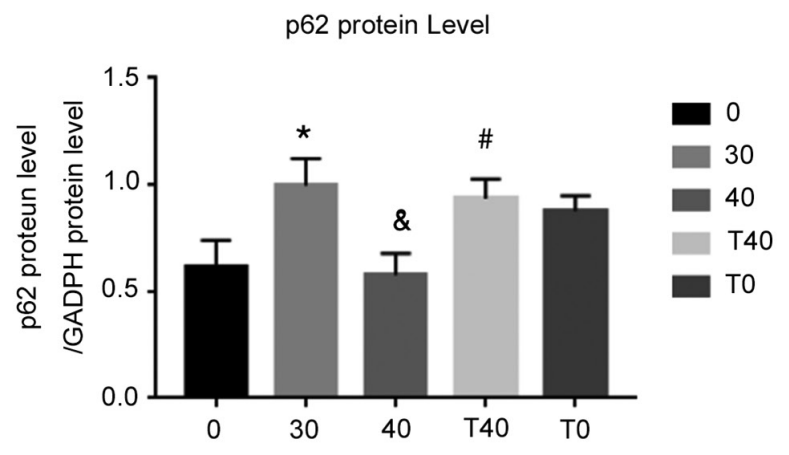

$\mathrm{D}$

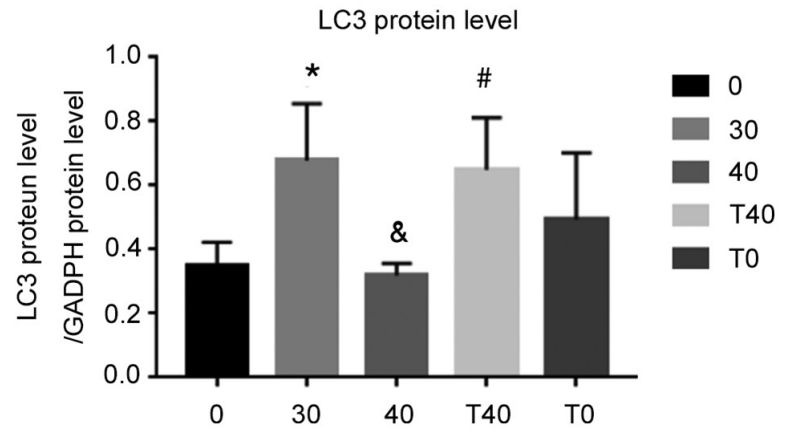

Figure 3. Changes in protein levels of NRF2, p62, HO-1 and LC3. Changes in (A) NRF2, (B) p62, (C) HO-1 and (D) LC3 protein levels following different treatments. GADPH was used as the internal control. All experiments were performed in triplicate ( $\mathrm{n}=3)$. ${ }^{*} \mathrm{P}<0.05 \mathrm{vs} .0 \mu \mathrm{g} / \mathrm{ml}$ ozone; ${ }^{\circledR} \mathrm{P}<0.05 \mathrm{vs} .30 \mu \mathrm{g} / \mathrm{ml}$ ozone; ${ }^{"} \mathrm{P}<0.05$ vs. $40 \mu \mathrm{g} / \mathrm{ml}$ ozone. T40, $40 \mu \mathrm{mol} / \mathrm{l} \mathrm{tBHQ}+40 \mu \mathrm{g} / \mathrm{ml}$ ozone; T0, $40 \mu \mathrm{mol} / 1 \mathrm{tBHQ}$; NRF2, nuclear factor (erythroid-derived-2)-related 2; HO-1, heme oxygenase 1; LC3, light chain 3; tBHQ, tert-butylhydroquinone.

ozone. However, at $40 \mu \mathrm{g} / \mathrm{ml}$, absorbance at $520 \mathrm{~nm}$ decreased significantly (Fig. 2A). Thus, $40 \mu \mathrm{g} / \mathrm{ml}$ ozone was selected for subsequent experiments.

Changes in mRNA levels of NRF2 and HO-1 following ozone and $t B H Q$ treatment. RT-qPCR was used to assess the relative changes in mRNA levels of genes involved in redox homeostasis. No statistically significant difference was observed in the mRNA expression levels of p62 and LC3II following treatment with $40 \mu \mathrm{g} / \mathrm{ml}$ ozone compared with the control group (Fig. 2C and E). However, mRNA levels of NRF2 and HO-1 were increased in the T0 group [40 $\mu \mathrm{mol} / 1 \mathrm{tBHQ}$ treatment] compared with the control group, which indicated that tBHQ activated the NRF2 signaling pathway. The concentration of tBHQ selected in the present study was based on previous studies $(23,24)$. Furthermore, the levels of NRF2 increased more in the T40 than in the $40 \mu \mathrm{g} / \mathrm{ml}$ ozone group; levels of $\mathrm{HO}-1$ were lower in the $40 \mu \mathrm{g} / \mathrm{ml}$ ozone group compared with those in the $30 \mu \mathrm{g} / \mathrm{ml}$ ozone group. The addition of tBHQ in the T40 group did not result in a similar decrease in HO-1 (Fig. 2B and D).

High ozone dose alters expression levels of proteins in the NRF2/ARE pathway. Protein levels of NRF2 and HO-1 were assessed to determine changes in the NRF2/ARE pathway following ozone administration. Protein levels of NRF2 and HO-1 were increased in the $30 \mu \mathrm{g} / \mathrm{ml}$ ozone group compared with the $0 \mu \mathrm{g} / \mathrm{ml}$ ozone group, and HO-1 levels were decreased in the 40 and $30 \mu \mathrm{g} / \mathrm{ml}$ ozone groups. Conversely, treatment with tBHQ in the T40 group reversed the changes in protein expression levels observed in the $40 \mu \mathrm{g} / \mathrm{ml}$ ozone group (Fig. 3A and C).

Protein levels of both p62 and LC3II increased in the $30 \mu \mathrm{g} / \mathrm{ml}$ ozone group, compared with the $0 \mu \mathrm{g} / \mathrm{ml}$ ozone group, and decreased in the $40 \mu \mathrm{g} / \mathrm{ml}$ ozone group compared with the $30 \mu \mathrm{g} / \mathrm{ml}$ ozone group. Moreover, tBHQ reversed the downregulation of p62 and LC3II in the $40 \mu \mathrm{g} / \mathrm{ml}$ ozone group (Fig. 3B and D). Certain reports have shown that p62 can form 
A

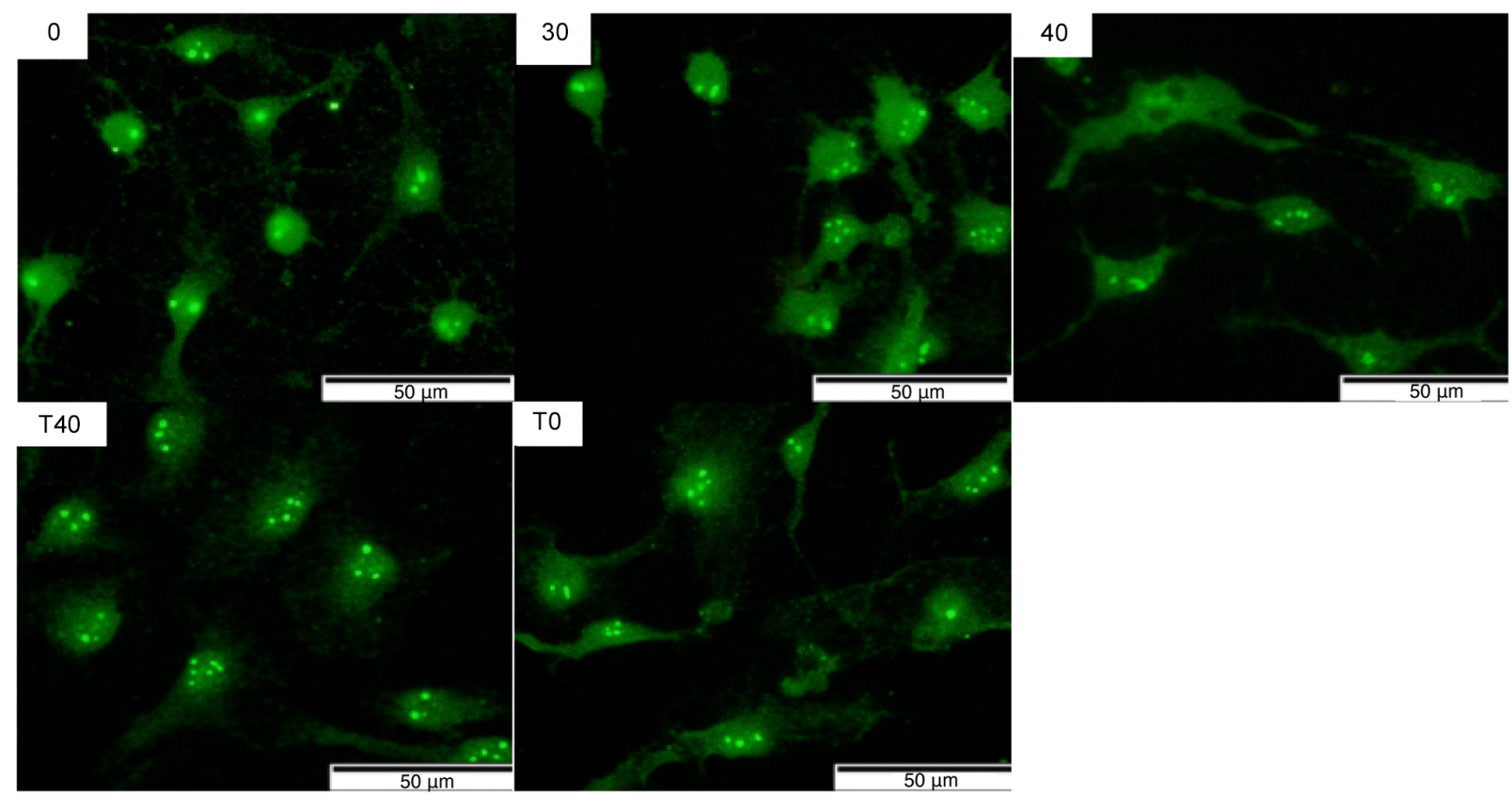

B

Nuclear NRF2 puncta

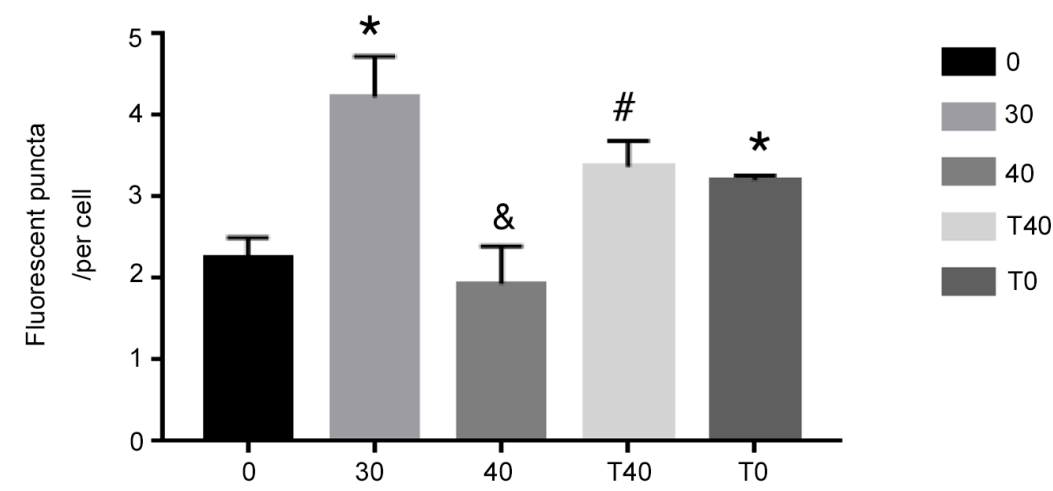

Figure 4. Change in nuclear NRF2 expression levels. (A) Immunofluorescence staining of NRF2 shows expression of NRF2 in the nucleus. (B) Change in nuclear NRF2 expression levels following treatment. The data are presented as the mean $\pm \mathrm{SD}(\mathrm{n}=3)$. ${ }^{*} \mathrm{P}<0.05 \mathrm{vs} .0 \mu \mathrm{g} / \mathrm{ml}$ ozone; ${ }^{\&} \mathrm{P}<0.05 \mathrm{vs}$. $30 \mu \mathrm{g} / \mathrm{ml}$ ozone; ${ }^{\text {"P }}<0.05$ vs. $40 \mu \mathrm{g} / \mathrm{ml}$ ozone. T40, $40 \mu \mathrm{mol} / 1 \mathrm{tBHQ}+40 \mu \mathrm{g} / \mathrm{ml}$ ozone; T0, $40 \mu \mathrm{mol} / 1 \mathrm{tBHQ}$; NRF2, nuclear factor (erythroid-derived-2)-related 2; tBHQ, tert-butylhydroquinone.

A

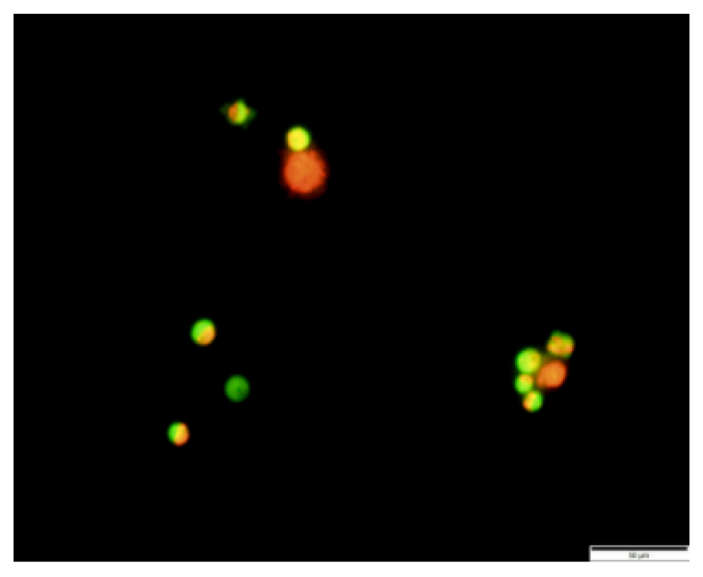

B

Cell counts of apoptosi and necrosis

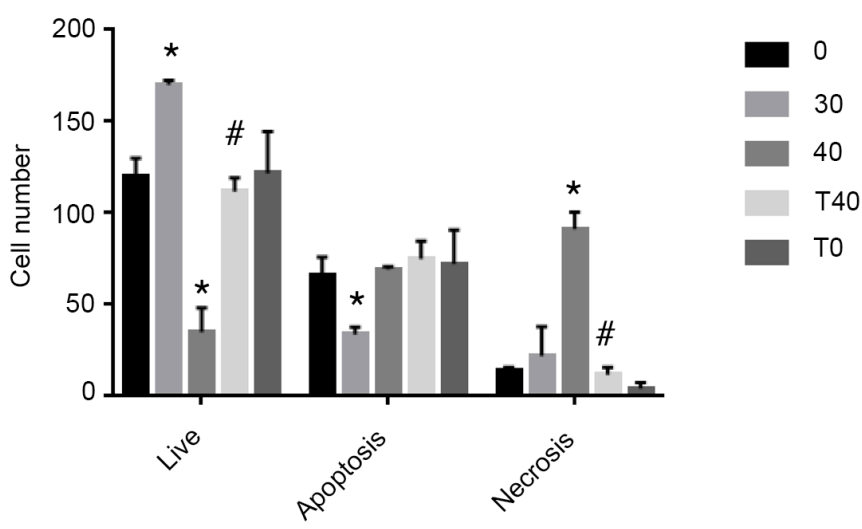

Figure 5. Change in cell viability. (A) Immunofluorescent staining by Normal/Apoptotic/Necrotic Cell Detection kit. Green, live cells; orange, necrotic cells; mixed green and orange, apoptotic cells (scale bar, $50 \mu \mathrm{m}$ ). (B) Normal, apoptotic and necrotic cells following treatment. All experiments were performed in triplicate (n=3). "P<0.05 vs. $0 \mu \mathrm{g} / \mathrm{ml}$ ozone; ${ }^{\#} \mathrm{P}<0.05$ vs. $40 \mu \mathrm{g} / \mathrm{ml}$ ozone. T40, $40 \mu \mathrm{mol} / 1 \mathrm{tBHQ}+40 \mu \mathrm{g} / \mathrm{ml}$ ozone; T0, $40 \mu \mathrm{mol} / 1 \mathrm{tBHQ}$; tBHQ, tert-butylhydroquinone. 
a positive feedback loop with KEAP1 and NRF2 (9,25), and that expression levels of p62 and LC3II responds to the level of autophagy.

NRF2 localizes to the nucleus and increases in the $30 \mu \mathrm{g} / \mathrm{ml}$ ozone, T40 and T0 groups. Cytoplasmic NRF2 localizes to the nucleus, activating ARE and increasing antioxidant levels (26). NRF2 levels in the nucleus were detected by immunofluorescence, which showed that nuclear NRF2 increased in the $30 \mu \mathrm{g} / \mathrm{ml}$ ozone group compared with the $0 \mu \mathrm{g} / \mathrm{ml}$ ozone group. However, the $40 \mu \mathrm{g} / \mathrm{ml}$ ozone group exhibited less nuclear NRF2 than the $30 \mu \mathrm{g} / \mathrm{ml}$ ozone group. Treatment with $\mathrm{tBHQ}$ in the T40 group reversed this decrease in nuclear NRF2 (Fig. 4A and B).

tBHQ reverses ozone-induced cell death. CCK8 assay showed that $30 \mathrm{~min}$ ozone therapy at $40 \mu \mathrm{g} / \mathrm{ml}$ decreased cell viability by $71 \%$. AO/EB assay was used to verify whether tBHQ prevent and SCN death caused by $40 \mu \mathrm{g} / \mathrm{ml}$ ozone treatment (Fig. 5A). Confirming the findings of the CCK8 assay, the results showed a decrease in live cells and an increase in necrotic cells in the $40 \mu \mathrm{g} / \mathrm{ml}$ ozone (Fig. 5B). Conversely, a decrease in necrosis and increase in live cells was observed in the T40 group compared with the $40 \mu \mathrm{g} / \mathrm{ml}$ ozone group.

\section{Discussion}

The effects of ozone, a gas with strong oxidizing properties, are concentration-dependent (4). Overuse of ozone can affect redox homeostasis and the central nervous system is easily influenced by ozone due to its high oxygen requirement. SCNs were here extracted from newborn Wistar rats and subjected to different ozone concentrations. Similar to a previous report, $40 \mu \mathrm{g} / \mathrm{ml}$ ozone injured the neurons in vitro (4).

Here, $40 \mu \mathrm{g} / \mathrm{ml}$ ozone induced death of SCNs in vitro, and mRNA and protein levels of HO-1 decreased with higher concentrations of ozone ( 30 and $40 \mu \mathrm{g} / \mathrm{ml}$ ). Moreover, protein levels of NRF2, p62 and LC3II and expression of nuclear NRF2 decreased in the $40 \mu \mathrm{g} / \mathrm{ml}$ ozone group compared with the $30 \mu \mathrm{g} / \mathrm{ml}$ ozone group. Furthermore, tBHQ prevented this decrease in the $40 \mu \mathrm{g} / \mathrm{ml}$ ozone group.

Ozone has a strong oxygen-saturation capacity, and medical ozone is a mixture of ozone and oxygen with over 100 years of clinical use. It can interact with organic macromolecules to induce the production of reactive oxygen species (ROS) and lipid oxidation products (LOPS) to treat disease (27). However, the antioxidant system is damaged if excessive ozone concentrations imbalance ROS and LOPS (28). Previously, several pathways have been implicated in redox homeostasis $(29,30)$. Reports have shown that the KEAP1/NRF2/ARE pathway is important to counteracting oxidative stress (31) and that autophagy is sensitive to oxidative stress (32). p62, a key protein in autophagy, also regulates the activation of the KEAP1/NRF2/ARE pathway (33). Based on these studies, tBHQ (an activator of NRF2), was used to investigate the role of the p62/KEAP1/NRF2/ARE pathway in responding to the damage caused to SCNs by ozone overdose.

The NRF2/ARE pathway is a key pathway in antioxidative stress signaling (31). It participates in all processes of the neuron system (13-15) and is critical in supporting the normal activity of the nervous system. In the present study, $40 \mu \mathrm{g} / \mathrm{ml}$ ozone decreased the mRNA levels of HO-1, and similar decreases in protein expression levels of NRF2 and HO-1 were observed. Similarly, p62 protein levels decreased with ozone treatment. Moreover, NRF2 localizes to the nucleus to activate ARE and enhance antioxidant capacity (33); the present study showed that treatment with ozone increased expression levels of nuclear NRF2. tBHQ reversed the changes in protein and mRNA expression levels observed due to administration of $40 \mu \mathrm{g} / \mathrm{ml}$ ozone. Following treatment with tBHQ and $40 \mu \mathrm{g} / \mathrm{ml}$ ozone, nuclear NRF2 expression levels and necrosis rate decreased. These results showed that ozone overdose induced autophagy in SCNs by inhibiting the activity of NRF2/ARE, and that tBHQ activated NRF2 to protect SCNs.

Autophagy is the major intracellular degradation system that is crucial in protecting cells from injury (34) and serves a key role in nervous system disease (9-12). p62 is a key protein in autophagy and, together with LC3II, reflects autophagy in cells (35). Conversely, p62 and NRF2 form a positive feedback loop to enhance antioxidant capacity to protect cells (8). On this basis, changes in p62 and LC3II were measured. Previous studies have demonstrated that autophagic capacity is enhanced by increased LC3II and decreased p62 (36-38). Conversely, autophagic capacity decreases if the reverse result is obtained (39). No changes were observed in the mRNA levels of p62 and LC3II, and decreases in p62 and LC3II protein levels were only observed following $40 \mu \mathrm{g} / \mathrm{ml}$ ozone treatment; tBHQ reversed this decrease in p62 and LC3II protein levels. Moreover, tBHQ increased the expression levels of LC3II, thus showing that autophagic flux was activated. However, expression of p62 also increased. This may have been due to simultaneous activation of autophagy (40) and the NRF2/ARE pathway (19) by ozone in combination with tBHQ treatment. This positive feedback increased the expression of p62 observed in the present study. Thus, it was concluded that $\mathrm{BHQ}$ activates autophagy and the p62/NRF2/ARE pathway to increase nuclear NRF2 localization and enhance the antioxidant system, which may protect cells from injury caused by ozone overdose.

Certain limitations exist in the present study. For example, the mechanism proposed should be further scrutinized by arresting the rise in NRF2 following tBHQ treatment. Additionally, other autophagy signaling pathways, such as $\mathrm{PI} 3 \mathrm{~K} / \mathrm{Akt} / \mathrm{mTOR}$, should be investigated for potential interactions with p62 and LC3II. Other apoptotic proteins, such as cytochrome c, activating transcription factor, Bax, Bid and caspase-3/9, should also be assessed to clarify the mechanism underlying ozone and the protective effect of tBHQ. Finally, the mechanism proposed here needs to be tested in vivo to identify clinical applications.

The present study proposed a potential mechanism of SCN injury caused by ozone overdose. The results suggest that $40 \mu \mathrm{g} / \mathrm{ml}$ ozone injured SCNs in vitro. Furthermore, $40 \mu \mathrm{g} / \mathrm{ml}$ ozone disrupted the p62/NRF2/ARE pathway and disturbed NRF2 nuclear transfer to injure SCNs. While this study presents in vitro data about the protective role of nuclear NRF2 localization, data from in vivo studies are still required.

\section{Acknowledgements}

Not applicable. 


\section{Funding}

The present study was funded by the National Natural Science Foundation of China (grant nos. 81271346 and 81771199).

\section{Availability of data and materials}

The datasets used and/or analyzed during the current study are available from the corresponding author on reasonable request.

\section{Authors' contributions}

ZF, CZ and XZ conceptualized and designed the experiments. $\mathrm{CZ}$ and $\mathrm{XZ}$ performed the experiments. BW, PS and SM performed data analysis. $\mathrm{CZ}$ and $\mathrm{BW}$ wrote the manuscript. $\mathrm{CZ}$ and $\mathrm{ZF}$ confirm the authenticity of all the raw data. All authors read and approved the final manuscript.

\section{Ethics approval and consent to participate}

All animal experiments were approved by the Animal Care and Use Committee of Shandong Provincial Hospital Affiliated to Shandong University (approval no. 2020-663).

\section{Patient consent for publication}

Not applicable.

\section{Competing interests}

The authors declare that they have no competing interests.

\section{References}

1. Anuj B, Peter M, Donald L, Elias G and Murphy K: Percutaneous ozone treatment for herniated lumbar discs: 1-year follow-up of a multicenter pilot study of a handheld disposable ozone-generating device. J Vasc Interv Radiol 30: 752-760, 2019

2. Silva Júnior JIS, Rahal SC, Santos IFC, Martins DJC, Michelon F, Mamprim MJ, Tomacheuski RM and Correia LECS: Use of reticulated hyaluronic acid alone or associated with ozone gas in the treatment of osteoarthritis due to hip dysplasia in dogs. Front Vet Sci 7: 265, 2020

3. Ginanneschi F, Cervelli C, Milani P and Rossi A: Ventral and dorsal root injury after oxygen-ozone therapy for lumbar disk herniation. Surg Neurol 66: 619-620, 2006.

4. Liu H, Wang Y, An J, Williams J and Cope D: Thunderclap headache caused by an inadvertent epidural puncture during oxygen-ozone therapy for patient with cervical disc herniation. Chin Med J (Engl) 129: 498-499, 2016.

5. Özugur S, Kunz L and Straka H: Relationship between oxygen consumption and neuronal activity in a defined neural circuit. BMC Biol 18: 76, 2020.

6. Li Y, Lin X, Zhao X, Xie J, JunNan W, Sun T and Fu Z: Ozone (O3) elicits neurotoxicity in spinal cord neurons (SCNs) by inducing ER $\mathrm{Ca}(2+)$ release and activating the CaMKII/MAPK signaling pathway. Toxicol Appl Pharmacol 280: 493-501, 2014

7. Rivas-Arancibia S, Guevara-Guzmán R, López-Vidal Y, Rodríguez-Martínez E, Zanardo-Gomes M, Angoa-Pérez M and Raisman-Vozari R: Oxidative stress caused by ozone exposure induces loss of brain repair in the hippocampus of adult rats. Toxicol Sci 113: 187-197, 2010.

8. Jiang G, Xue L, Huang Y, Lan Z, Zhang Z, Su Z, Fang Z, Lai Y, Yao W, Ting L, et al: p62 promotes proliferation, apoptosis-resistance and invasion of prostate cancer cells through the Keap1/Nrf2/ARE axis. Oncol Rep 43: 1547-1557, 2020.

9. Li T, Jiang D and Wu K: p62 promotes bladder cancer cell growth by activating KEAP1/NRF2-dependent antioxidative response. Cancer Sci 111: 1156-1164, 2020.
10. Liao W, Wang Z, Fu Z, Ma H, Jiang M, Xu A and Zhang W: p62/SQSTM1 protects against cisplatin-induced oxidative stress in kidneys by mediating the cross talk between autophagy and the Keap1-Nrf2 signalling pathway. Free Radic Res 53: 800-814, 2019.

11. Yuan B, Shen H, Lin L, Su T, Zhong L and Yang ZJ: Autophagy promotes microglia activation through beclin-1-atg 5 pathway in intracerebral hemorrhage. Mol Neurobiol 54: 115-124, 2017.

12. Lipton J and Sahin MJN: The neurology of mTOR. Neuron 84: 275-291, 2014.

13. Sepe S, Nardacci R, Fanelli F, Rosso P, Bernardi C, Cecconi F, Mastroberardino PG, Piacentini M and Moreno S: Expression of Ambra1 in mouse brain during physiological and Alzheimer type aging. Neurobiol Aging 35: 96-108, 2014.

14. Zhou Z, Chen S, Zhao H, Wang C, Gao K, Guo Y, Shen Z, Wang Y, Wang $\mathrm{H}$ and Mei X: Probucol inhibits neural cell apoptosis via inhibition of mTOR signaling pathway after spinal cord injury. Neuroscience 329: 193-200, 2016.

15. Li D, Tian H, Li X, Mao L, Zhao X, Lin J, Lin S, Xu C, Liu Y, Guo $\mathrm{Y}$ and Mei X: Zinc promotes functional recovery after spinal cord injury by activating $\mathrm{Nrf} 2 / \mathrm{HO}-1$ defense pathway and inhibiting inflammation of NLRP3 in nerve cells. Life Sci 245: $117351,2020$.

16. Wen C, Huang C, Yang M, Fan C, Li Q, Zhao J, Gan D, Li A, Zhu L and Lu D: The secretion from bone marrow mesenchymal stem cells pretreated with berberine rescues neurons with oxidative damage through activation of the keap1-nrf2-ho-1 signaling pathway. Neurotox Res 38: 59-73, 2020.

17. Xu C, Hou B, He P, Ma P, Yang X, Yang X, Zhang L, Qiang G, $\mathrm{Li}$ W and Du G: Neuroprotective Effect of salvianolic acid a against diabetic peripheral neuropathy through modulation of nrf2. Oxid Med Cell Longev 2020: 6431459, 2020.

18. Nna VU, Ujah GA, Suleiman JB, Mohamed M, Nwokocha C, Akpan TJ,Ekuma HC, Fubara VV, Kekung-Asu CB and Osim EE: Tert-butylhydroquinone preserve testicular steroidogenesis and spermatogenesis in cisplatin-intoxicated rats by targeting oxidative stress, inflammation and apoptosis. Toxicology 441: 152528, 2020.

19. Meng X, Zhang C, Guo Y, Han Y, Wang C, Chu H, Kong L, Ma H and Saso L: TBHQ attenuates neurotoxicity induced by methamphetamine in the VTA through the Nrf2/HO-1 and PI3K/AKT signaling pathways. Oxid Med Cell Longev 2020: 8787156, 2020.

20. Ratliff WA, Delic V, Pick CG and Citron BA: Dendritic arbor complexity and spine density changes after repetitive mild traumatic brain injury and neuroprotective treatments. Brain Res 1746: 147019, 2020.

21. Muri J, Wolleb H, Broz P, Carreira EM and Kopf M: Electrophilic Nrf2 activators and itaconate inhibit inflammation at low dose and promote IL-1 $\beta$ production and inflammatory apoptosis at high dose. Redox Biol 36: 101647, 2020.

22. Livak KJ and Schmittgen TD: Analysis of relative gene expression data using real-time quantitative PCR and the 2(-Delta Delta C(T)) method. Methods 25: 402-408, 2001.

23. Li H, Wu S, Shi N, Lin W, You J and Zhou W: NF-E2-related factor 2 activation in PC12 cells: Its protective role in manganese-induced damage. Arch Toxicol 85: 901-910, 2011.

24. Xu W, Li F, Xu Z, Sun B, Cao J and Liu Y: Tert-butylhydroquinone protects PC12 cells against ferrous sulfate-induced oxidative and inflammatory injury via the Nrf2_ARE pathway. Chem Biol Interact 273: 28-36, 2017.

25. Gureev A, Sadovnikova I, Starkov N, Starkov A and Popov V: p62-Nrf2-p62 mitophagy regulatory loop as a target for preventive therapy of neurodegenerative diseases. Brain Sci 10: 847, 2020.

26. Jena KK, Kolapalli SP, Mehto S, Nath P, Das B, Sahoo PK, Ahad A, Syed GH, Raghav SK, Senapati S, et al: TRIM16 controls assembly and degradation of protein aggregates by modulating the p62-NRF2 axis and autophagy. EMBO J 37: e98358, 2018.

27. Bocci V, Valacchi G, Corradeschi F, Aldinucci C, Silvestri S, Paccagnini E and Gerli R: Studies on the biological effects of ozone: 7. Generation of reactive oxygen species (ROS) after exposure of human blood to ozone. J Biol Regul Homeost Agents 12: 67-75, 1998.

28. Sagai M and Bocci V: Mechanisms of action involved in ozone therapy: Is healing induced via a mild oxidative stress? Med Gas Res 1: 29, 2011.

29. Jimenez-Moreno N and Lane JD: Autophagy and redox homeostasis in Parkinson's: A crucial balancing Act. Oxid Med Cell Longev 2020: 8865611, 2020. 
30. Ferino A, Rapozzi V and Xodo LE: The ROS-KRAS-Nrf2 axis in the control of the redox homeostasis and the intersection with survival-apoptosis pathways: Implications for photodynamic therapy. J Photochem Photobiol B 202: 111672, 2020.

31. Kensler TW, Wakabayashi N and Biswal S: Cell survival responses to environmental stresses via the Keap1-Nrf2-ARE pathway. Annu Rev Pharmacol Toxicol 47: 89-116, 2007.

32. Filomeni G, Zio DD and Cecconi F: Oxidative stress and autophagy: The clash between damage and metabolic needs. Cell Death Differ 22: 377-388, 2015.

33. Liu Q, Tan Y, Qu T, Zhang J, Duan X, Xu H, Mu Y, Ma H and Wang F: Therapeutic mechanism of human neural stem cell-derived extracellular vesicles against hypoxia-reperfusion injury in vitro. Life Sci 254: 117772, 2020.

34. Mizushima N and Komatsu MJC: Autophagy: Renovation of cells and tissues. Cell 147: 728-741, 2011.

35. Kim T, Lee S, Kim M, Cheon C and Ko SG: Kaempferol induces autophagic cell death via IRE1-JNK-CHOP pathway and inhibition of G9a in gastric cancer cells. Cell Death Dis 9: 875, 2018.

36. Kadowaki M and Karim MR: Cytosolic LC3 ratio as a quantitative index of macroautophagy. Methods Enzymol 452: 199-213, 2009.
37. Min Z, Ting Y, Mingtao G, Xiaofei T, Dong Y, Chenguang Z and Wei D: Monitoring autophagic flux using p62/SQSTM1 based luciferase reporters in glioma cells. Exp Cell Res 363: 84-94, 2018.

38. Kimura S, Fujita N, Noda T and Yoshimori T: Monitoring autophagy in mammalian cultured cells through the dynamics of LC3. Methods Enzymol 452: 1-12, 2009.

39. Sheng Y, Chen X, Hou X, Yuan X, Yuan BS, Yuan YQ Zhang QL, Cao X, Liu CF, Luo WF and Hu LF: Urate promotes $\mathrm{SNCA} / \alpha$-synuclein clearance via regulating mTOR-dependent macroautophagy. Exp Neurol 297: 138-147, 2017.

40. Li S, Li J, Shen C, Zhang X, Sun S, Cho M, Sun C and Song Z: Tert-Butylhydroquinone (tBHQ) protects hepatocytes against lipotoxicity via inducing autophagy independently of Nrf2 activation. Biochim Biophys Acta 1841: 22-33, 2014.

This work is licensed under a Creative Commons Attribution-NonCommercial-NoDerivatives 4.0 International (CC BY-NC-ND 4.0) License. 